Bull. Geol. Soc. Finland 42, 3-12 (1970)

\title{
PYRRHOTITE-TROILITE INTERGROWTH FROM LUIKONLAHTI COPPER DEPOSIT, EASTERN FINLAND
}

\author{
Atso Vorma \\ Geological Survey of Finland, Otaniemi, Finland
}

\begin{abstract}
A homoaxial intergrowth of troilite with iron-deficient pyrrhotite, $\mathrm{Fe}_{0 \cdot 921} \mathrm{~S}$, is described. X-ray single crystal study of the pyrrhotite component points to a superstructure with $c=11 C$ and apparently to an orthorhombic symmetry. The intergrowth occurs on fissure walls in serpentinite rock as euhedral long-prismatic crystals; it apparently formed at a very low temperature. Possibly a simultaneous crystallization of troilite and iron-deficient pyrrhotite took place.
\end{abstract}

\section{Introductory note}

While visiting the Luikonlahti copper mine in eastern Finland in 1967, Professor V. Marmo, Director of the Geological Survey of Finland, was shown a mineral specimen containing pyrrhotite of a quite exceptional habitus. On his initiative, the present author undertook the investigation of this specimen with its long-prismatic, often needle-like pyrrhotite crystals. Two other specimens taken from the same spot in the mine were kindly put at the author's disposal by Mr. Ossi Näykki, Lic. Phil., of the Dept. of Geology and Mineralogy, University of Helsinki. The paper at hand is based on a study of these three samples.

\section{Occurrence}

The specimens are from the serpentinite of Luikonlahti and in each specimen the surface of a fissure wall is represented. A layer of crypto- crystalline serpentine, less than $1 \mathrm{~mm}$ thick, covers the wall surface. Repeated layering is to be observed the bottom layer being microcrystalline. Large pyrrhotite crystals which are often needle-like and always elongated parallel to their crystallographic $c$-axis have grown on the serpentine layer. The $c$-axes are directed parallel or subparallel to the fissure wall. On the wall plane the crystals are oriented at random. Calcite crystals, from $0.5 \mathrm{~mm}$ to $5 \mathrm{~mm}$ in diameter, and pseudohexagonal crystals of serpentine accompany the pyrrhotite crystals. Pyrrhotite occurs either as separate euhedral crystals or as crystal bundles in which the $c$-axes are subparallel (Fig. 1). The length of the needle-like pyrrhotite crystals varies from $0.1 \mathrm{~mm}$ to $5 \mathrm{~mm}$; their breadth occasionally reaches up to $1 \mathrm{~mm}$. A number of the pyrrhotite crystals and crystal bundles are coated by cryptocrystalline serpentine (Fig. 2), which forms shells of various colours around the pyrrhotite prism (Fig. 3). 


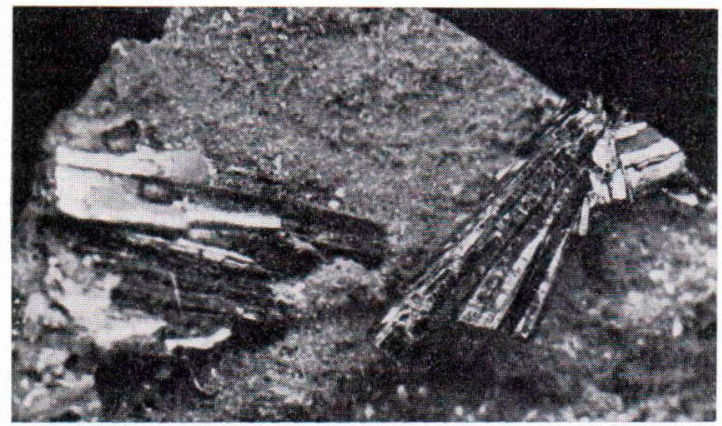

Fig. 1. Crystal bundles of pyrrhotite on fissure wall in serpentinite. Magn. 10.5 x. Photo Erkki Halme.

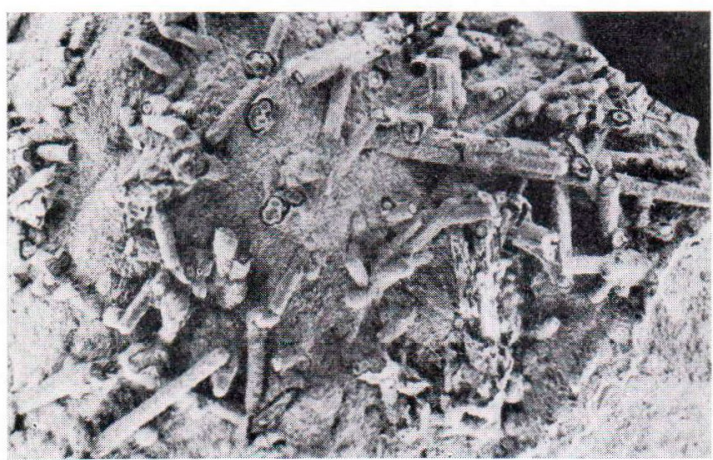

Fig. 2. Pyrrhotite crystals elongated parallel to the $c$-axis and coated by shells of cryptocrystalline serpentine. Magn. 2.9 x. Photo Erkki Halme.

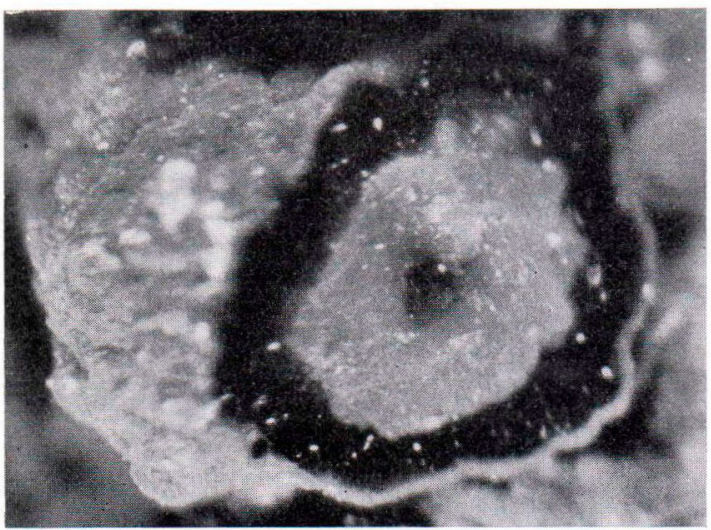

Fig. 3. Cross section of a pyrrhotite crystal coated by serpentine shells. The black spot at the center is pyrrhotite. Magn. 30 x. Photo Erkki Halme.

\section{Morphology and physical properties}

The Luikonlahti pyrrhotite shows very welldeveloped crystal forms (Figs. 4 and 5). It belongs, thus, to the exceptions among the descriptions of the habitus of pyrrhotite (see, e.g., Mandarino and Mitchell, 1960). The habitus of Luikonlahti pyrrhotite is characterized by a welldeveloped prism form. All the observed crystal forms are simple: $m\{10 \overline{10}\}, r\{10 \overline{1} 1\}$ and $c\{0001\}$ when the axes of NiAs-type structure are used. Using the troilite axes, the corresponding forms are $\{11 \overline{2} 0\},\{11 \overline{2} 2\}$ and $\{0001\}$. The prismatic

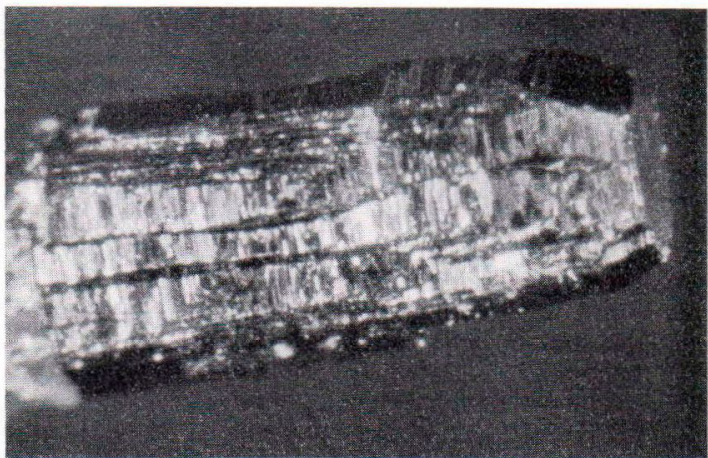

Fig. 4. Euhedral pyrrhotite crystal displaying the prismal form $m\{10 \overline{1} 0\}$, the pyramidal form $r\{10 \overline{1} 1\}$ and the basal plane $c\{0001\}$. The striation parallel to (0001) is clearly seen. The striation parallel to [0001] is due to twinning. Magn. 53 x. Photo Erkki Halme.

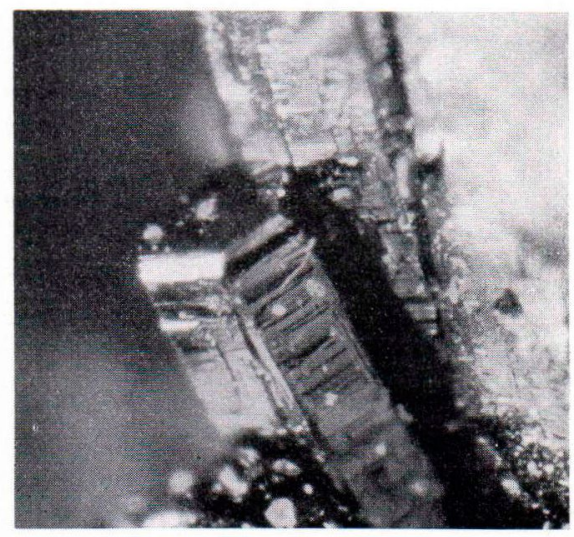

Fig. 5. Euhedral pyrrhotite crystal displaying the same forms as in Fig. 4. The striation parallel to (0001) is due to the alternation of prismal and pyramidal forms. Magn. 100 x. Photo Erkki Halme. 
and pyramidal faces are usually striated parallel to (0001) (Figs. 4 and 5). This is due partly to the alternation of prismatic and pyramidal forms (Fig. 5), partly also to the alternation of troilite and pyrrhotite lamellae within the crystal. Under the microscope the mineral exhibits faint flamelike lamellae-texture. The texture is seen clearly when etched polished sections are used (a saturated $\mathrm{CrO}_{3}$ in water). The etched crystals show that the individuals usually consist of two zones

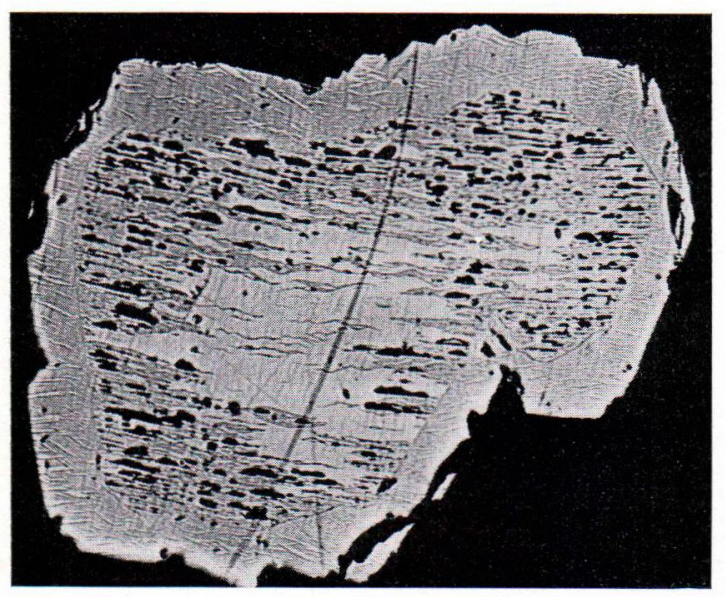

Fig. 6. Polished section, subparallel to the (0001) plane of pyrrhotite. Oxidized by $\mathrm{CrO}_{3}$. Troilite, lighter in colour, and iron-deficient pyrrhotite, darker in colour. Note the zonal texture. Magn. 73 x. Photo Erkki Halme.

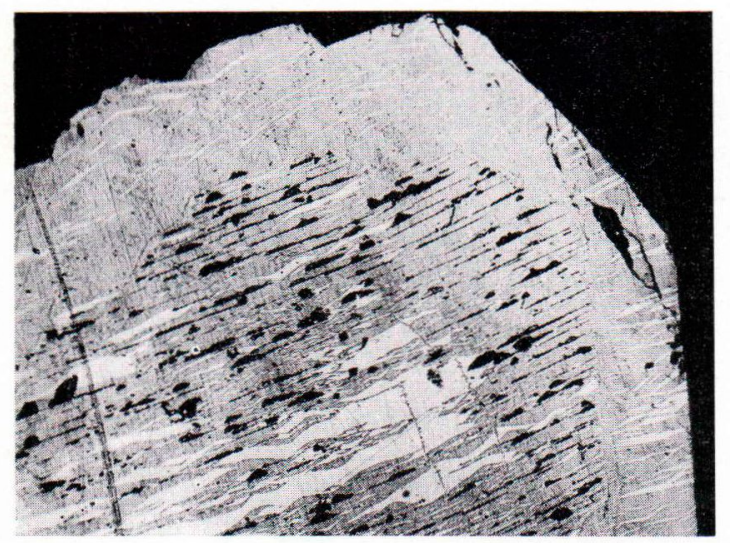

Fig. 7. Part of polished section shown in Fig. 6. Note the zonal texture. The iron-deficient pyrrhotite, darker in colour on oxidized surface, shows marked $\{0001\}$ cleavage in the core zone of the intergrowth. Magn. $190 \mathrm{x}$. Photo Erkki Halme.

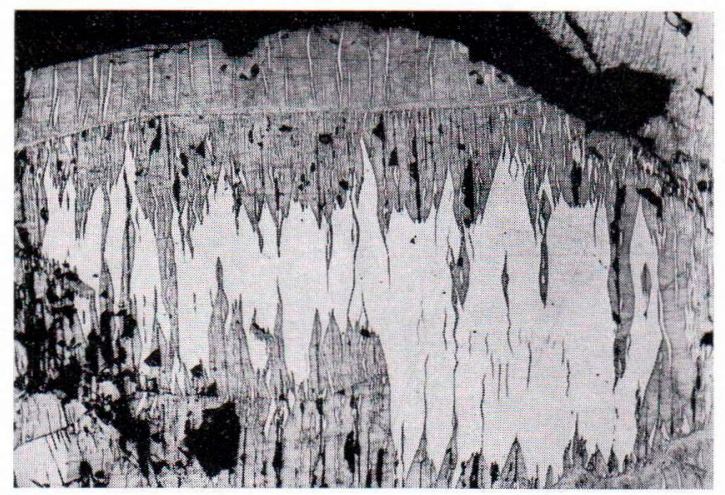

Fig. 8. Polished section, parallel to the hexagonal $c$-axis (horizontal direction in the figure) of troilite, oxidized by $\mathrm{CrO}_{3}$. The unoxidized phase, lighter in colour, is troilite. The upper side and the lower right corner in the figure are represented by iron-deficient pyrrhotite of the marginal zone with minor flame-like lamellae of troilite. The major part of the figure is represented by the core zone. The composition plane of a twin in the pyrrhotitecomponent is seen in the lower part of the figure as a subhorizontal line. Magn. 190 x. Photo Erkki Halme.

(Figs. 6-8): a core and a marginal zone. The core consists mainly of trodite with flame-like lamellae of pyrrhotite, while the marginal zone is formed of pyrrhotite with some troilite as lamellae.

Both phases - troilite and pyrrhotite - have grown homoaxially. In most cases the pseudohexagonal pyrrhotite phase has twinned by 60 degrees' rotation about its pseudohexagonal caxis (Fig. 4). Well-developed traces of the $\{0001\}$ cleavage can be seen on etched polished section in the pyrrhotite of the core zone (Figs. 7 and 8). Corresponding traces are absent in the troilite component.

The pyrrhotite phase of the pyrrhotite-troilite intergrowth is apparently antiferromagnetic (nonmagnetic for a hand magnet) even though its crystal symmetry is definitely not hexagonal. No difference between the magnetic properties of the pyrrhotite component and the troilite component was detected when the polished section was treated with magnetite colloid (Strens, 1964). The sedimentation rates of magnetite on both phases were equal. 


\section{Chemical composition}

The chemical composition of the Luikonlahti pyrrhotite was determined both by $\mathrm{X}$-rays by the $d_{(102)}$-method of Arnold and Reichen (1962) and by electron microprobe. The results by the Xray method, both for the pyrrhotite phase and the troilite phase, are given in Table 1. The pyrrhotite phase corresponds in composition to the iron-deficient hexagonal pyrrhotite. In the troilite phase, there is a small excess of iron compared to the stoichiometric FeS. Since the determinative curve of Arnold and Reichen (1962) is based on a $d_{(102)}$-value which is somewhat too small

TABLE 1

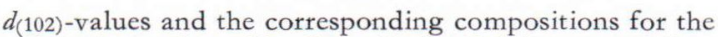
pyrrhotite and troilite from Luikonlahti copper mine, Kaavi, eastern Finland.

\begin{tabular}{|c|c|c|c|}
\hline & & Pyrrhotite & Troilite \\
\hline$d_{(102)}$ & $\begin{array}{l}\text { by precession } \\
\text { method }\end{array}$ & $2.0716 \AA$ & $2.0954 \AA$ \\
\hline$d_{(102)}$ & $\begin{array}{l}\text { by powder } \\
\text { method }\end{array}$ & $2.0721 \AA$ & $2.0944 \AA$ \\
\hline & $\begin{array}{l}\text { Mean } d_{(102)} \\
\text { Metals } \\
\mathrm{Fe}_{1-\mathrm{x}} \mathrm{S}\end{array}$ & $\begin{array}{l}2.0718 \AA \\
47.87 \text { atomic \% } \\
\mathrm{Fe}_{0.918} \mathrm{~S}\end{array}$ & $\begin{array}{l}2.0949 \AA \\
50.37 \text { atomic \% } \\
\mathrm{Fe}_{1.015} \mathrm{~S}\end{array}$ \\
\hline
\end{tabular}

Note: $d_{(102)}$-determinations by precession method are the means of two separate determinations, those by powder data the means of five determinations. In both methods, the film shrinkage is calibrated by silicon standard.

for troilite (Arnold, 1967, p. 32), the actual composition of the Luikonlahti troilite is between $\mathrm{FeS}$ and $\mathrm{Fe}_{1.015} \mathrm{~S}$. This troilite, with the supposed composition $\mathrm{FeS}$, was used as standard when the $\mathrm{Fe} / \mathrm{S}$ ratio in the pyrrhotite component of the intergrowth was determined by electron microprobe.

The microprobe determinations were run on five different profiles from pyrrhotite to troilite including runs across the border between the core and the marginal zone of the crystals. Only two different compositions were detected. One corresponds to troilite, the other to an irondeficient pyrrhotite. The mean of the five determinations gives a composition for pyrrhotite of: 61.29 wt. \% Fe and 38.21 wt. \% S, total 99.50 wt. \%. This corresponds to 47.94 atomic per cent $\mathrm{Fe}$ or to $\mathrm{Fe}_{0.921} \mathrm{~S}$, which is virtually the same as that determined by $\mathrm{X}$-rays by the $d_{(102)^{-}}$ method.

\section{X-ray crystallography}

The pyrrhotite structure, i.e., all the different superstructures recorded for pyrrhotite, has the hexagonal NiAs-structure as a basis. When the pyrrhotite unit cell dimensions are defined in the units of $A, B=A \sqrt{3}$ and $C$, where $A$ and $C$ are the hexagonal $a$ and $c$ parameters of the NiAs structure and $B$ the orthohexagonal $b$ parameter of the same structure (see Wuensch, 1963), the known pyrrhotite superstructure unit cells can be described as presented in Table 2. The superstructure in troilite is caused by small displacements of S atoms parallel to $c$ (Bertaut, 1956). The superstructures exhibited by the iron-deficient structures are primarily due to the ordered arrangement of the iron vacancies. Of the pyrrhotite superstructures in Table 2 only the hexagonal 2C-phase (troilite), the hexagonal $5 C$ phase and the monoclinic $4 C$-phase have been recorded from natural occurrences. The hexagonal (?) 4C-phase from Morro Velho, Brazil described by Buerger (1947) is evidently a twinned monoclinic 4C-phase (Wuensch, 1963).

Buerger precession photographs of Luikonlahti pyrrhotite were recorded to study the twinning and superstructure of the intergrowth. The crystal fragments investigated by the single crystal method were taken under the microscope from a polished section. Four fragments were from the core and one from the marginal zone of the intergrowth. In addition, two fairly small euhedral single crystals were investigated by the precession method. The three $a^{*}$-axes and the three $a$-axes (NiAs-structure type hexagonal axes) 
TABLE 2

The pyrrhotite superstructures.

\begin{tabular}{|c|c|c|c|}
\hline Superstructure & Composition & Symmetry & Remarks, references \\
\hline$B, 2 C, \ldots \ldots \ldots$ & $\mathrm{FeS}$ & Hexagonal & $\begin{array}{l}\text { Troilite. } \\
\text { Hägg and Sucksdorff (1933). }\end{array}$ \\
\hline $3 A, 2 C \ldots \ldots \ldots \ldots$ & "Slightly deficient in $\mathrm{Fe} »$ & Hexagonal & Artificial. Graham (1949). \\
\hline $2 A, 3 C \ldots \ldots \ldots \cdots$ & - & Apparently hexagonal & $\begin{array}{l}\text { With faults in addition to vacancy } \\
\text { defects. Corlett (1968). }\end{array}$ \\
\hline $2 B, 2 A, 4 C, \beta=90^{\circ} 40^{\prime}$ & near $\mathrm{Fe}_{7} \mathrm{~S}_{8}$ & Monoclinic & Bertaut (1953), Wuensch (1963). \\
\hline $2 A, 5 C \ldots \ldots \ldots \ldots$ & near $\mathrm{Fe}_{9} \mathrm{~S}_{10}$ & Dimensionally hexagonal & Carpenter and Desborough (1964). \\
\hline $2 A, 7 C \ldots \ldots \cdots \cdots$ & & Hexagonal & $\begin{array}{l}\text { Above } 315^{\circ} \mathrm{C} \text {. Desborough and } \\
\text { Carpenter (1965). }\end{array}$ \\
\hline $2 A, 2 B, 11 C \ldots$ & near $\mathrm{Fe}_{11} \mathrm{~S}_{12}$ & Orthorhombic or lower & This paper. \\
\hline
\end{tabular}

were used as precession axes. Zero, first, second and in some cases also third layers were recorded both of the troilite superstructure and of the pyrrhotite superstructure. The study was conducted so completely on only two single crystals. The number of precession photographs was more restricted in the five other single crystal studies. This sufficed, however, to show that only two phases exist in the samples and that the same two phases occur in the core and in the marginal zone

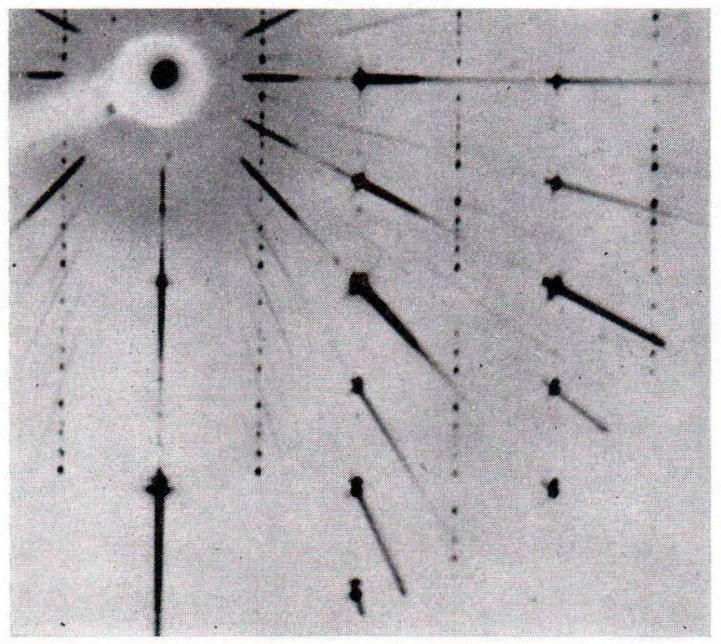

a

Fig. 9. a) $a$-axis zero level precession photograph of pyrrhotite twinned by rotation of 60 degrees about the pseudohexagonal $c$-axis and $a^{*}$-axis zero level of troilite. MoK $\alpha$-radiation. Vertical axis is the $c^{*}$ of both pyrrhotite and troilite, horizontal axis the $a^{*}$-axis (hexagonal axes) of pyrrhotite and the $a$-axis of troilite. Note the small of the crystals. This result is in accordance with that by electron microprobe analysis (see p. 6). The relative abundance of the troilite and irondeficient pyrrhotite phases varies from grain to grain.

As to the single crystal study of the troilite component, the conventional hexagonal superstructure $(B, 2 C)$ was recorded. The intergrowth with pyrrhotite is homoaxial. The mutual relation is seen in the photographs of Figs. 9 and 10,

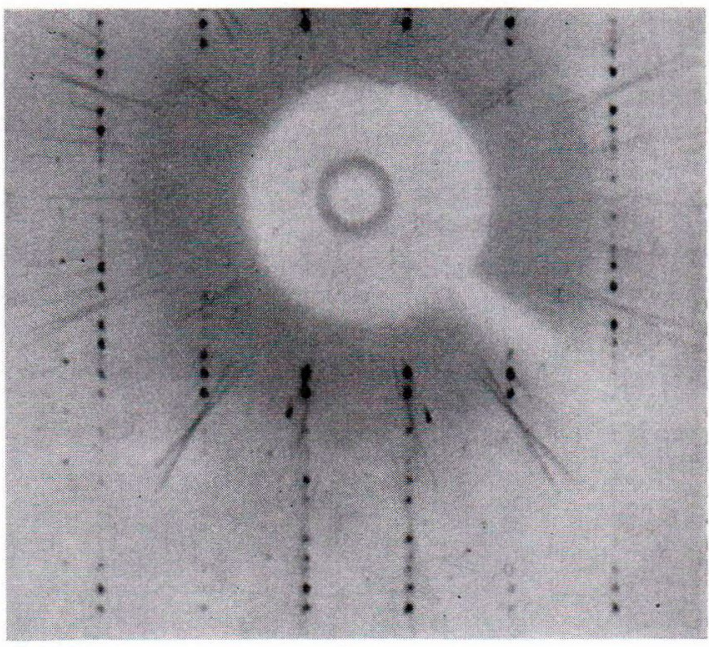

$\mathrm{b}$

displacements of some superlattice points parallel to $a^{*}$ causing the vertical symmetry line to disappear. Note also the additional reflections on the sublattice point rows $\left(\| c^{*}\right)$. b) Precession axis as in a. Same crystal as in a. First level of the pyrrhotite component. Note the superlattice point displacements parallel to the $a^{*}$-direction. 

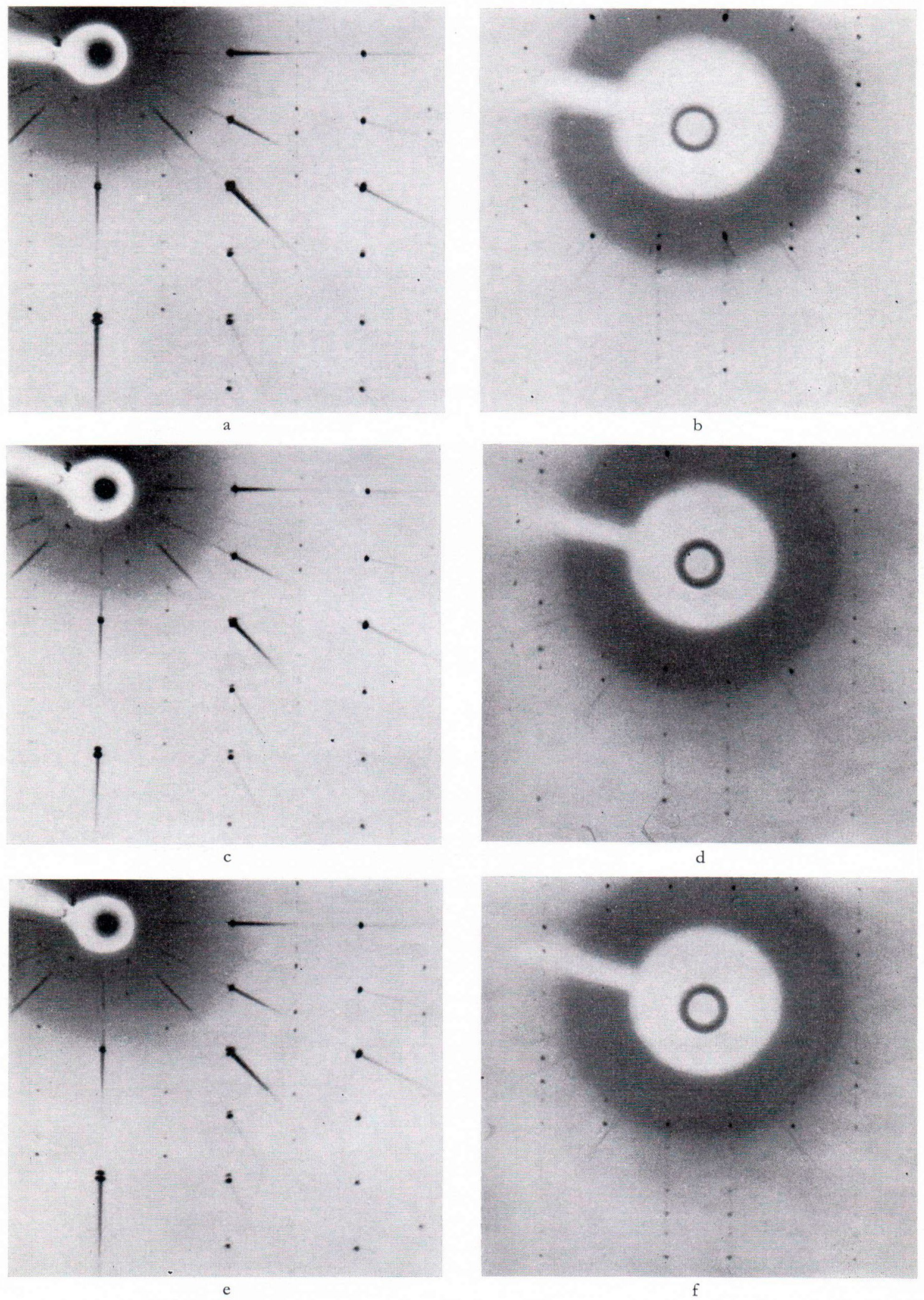


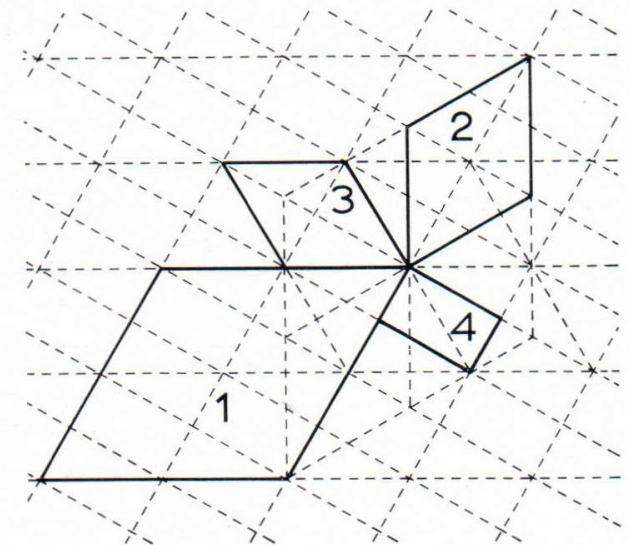

Fig. 11. The relation between the reciprocal cells recorded for the Luikonlahti pyrrhotite and troilite and the simple hexagonal reciprocal cell of the NiAs structure.

1. NiAs-type reciprocal cell, 2. troilite reciprocal cell,

3. pseudohexagonal pyrrhotite reciprocal cell, and 4 . orthorhombic pyrrhotite reciprocal cell. See Table 3.

and in Fig. 11 where the reciprocal cell projections along the $c$-axis are represented for some related structures.

The pyrrhotite component of the intergrowth gave precession photographs showing a marked superstructure. At first glance, the photographs seem to indicate a hexagonal superstructure with the $c$-axis equal to $11 C$ (Figs. $8 \mathrm{a}$ and $\mathrm{b}$ ). The $a$-axis precession photographs of the same layer, recorded at intervals of 60 degrees, are similar. A closer examination of the films, however, brings out small displacements of some of the superstructure points from their actual Bragg positions along the $a^{*}$-direction, suggesting twinning. These displacements prove that the geometry of the studied lattice deviates from that of the hexagonal lattice.

Fig. 10. Precession photographs of the untwinned $11 C$ pyrrhotite superstructure (and of the troilite). MoK $\alpha$ radiation. In each photograph the vertical axis is the $c^{*}$ and the horizontal axis the $a^{*}$-axis of the NiAs-type substructure.

a) $a_{1}$-axis zero level precession photograph. Both vertical and horizontal symmetry lines.

b) $a_{1}$-axis first level precession photograph of the pyrrhotite component. Only horizontal symmetry line. c) $a_{2}$-axis zero level precession photograph. Both vertical and horizontal symmetry lines.
Precession photographs of a crystal splinter cut with a razor blade under the microscope to less than $0.1 \mathrm{~mm}$ in diameter, show it to consist of untwinned pyrrhotite (Figs. 10, a-f) in as far as twinning is the cause of the displacements referred to. Of the $a_{1^{-}}, a_{2^{-}}$and $a_{3}$-axis (setting of axes consistent with the NiAs-structure) precession photographs recorded at 60 degrees' intervals not all are identical; this is true of both the zero level and higher level photographs, respectively. When the three photographs from the analogous level at intervals of 60 degrees are superimposed, they give an image identical with that of a single $a$-axis photograph of the twinned material. This proves that the twinning is due to a rotation of 60 degrees about the pseudohexagonal $c$-axis. The intensity correlation of the reflections in the different photographs of the untwinned pyrrhotite points to orthorhombic symmetry (Laue group $\mathrm{mmm}$ ). The reciprocal lattice projection along the $c$-axis is schematically shown in Fig. 12, where the hexagons represent the reciprocal lattice point rows, parallel to the $c^{*}$-axis, of the NiAs-type subcell. The reciprocal lattice point rows from the superlattice are represented in the figure by somewhat smaller symbols; identical rows have identical symbols.

Table 3 shows the relation of the orthorhombic pyrrhotite unit cell to its pseudohexagonal equivalent and to the troilite and NiAs-cells. Fig. 11 displays the relation of the corresponding reciprocal cells. The interpretation of the orthorhombic cell, however, should not be taken too formally. The cell of the Luikonlahti pyrrhotie certainly deviates from the cells of the hexagonal $5 C$ phase and the monoclinic $4 C$ phase. Some

d) $a_{2}$-axis first level precession photograph of the pyrrhotite component. Only horizontal symmetry line.

e) $a_{3}$-axis zero level precession photograph ([100]-axis zero level precession photograph, when the orthorhombic unit cell is used. Horizontal axis is [010]-direction). Both vertical and horizontal symmetry lines.

f) $a_{3}$-axis first level precession photograph of the pyrrhotite component. Both vertical and horizontal symmetry lines ( $c f$. Figs. b and d).

Note that Figs. b and d are mirror images of each other, This is due to the symmetry plane parallel to (100). 
TABLE 3

Unit cell sizes of NiAs, troilite and the Luikonlahti pyrrhotite.

\begin{tabular}{|c|c|c|c|}
\hline & a & b & $c$ \\
\hline $\begin{array}{l}\text { 1. NiAs } \ldots \ldots \ldots \ldots \ldots \ldots \ldots \ldots \ldots \ldots \\
\text { 2. Troilite } \ldots \ldots \ldots \ldots \ldots \ldots \ldots \\
\text { 3. Pyrrhotite, pseudohexagonal } \ldots \ldots \cdots \cdots \\
\text { 4. Pyrrhotite, orthorhombic } \ldots \ldots \ldots \cdots\end{array}$ & $\begin{array}{l}3.45 \AA=1 A \\
6.96 \AA=1 B \\
6.874 \AA=2 A \\
6.874 \AA=2 A\end{array}$ & $\begin{array}{l}- \\
\overline{-} \\
11.91 \AA=2 B\end{array}$ & $\begin{array}{l}5.8 \AA=1 C \\
11.72 \AA=2 C \\
63.2 \AA=11 C \\
63.2 \AA=11 C\end{array}$ \\
\hline
\end{tabular}

Note: Numbers $1-4$ refer to Fig. $10, B=A \sqrt{3}$.

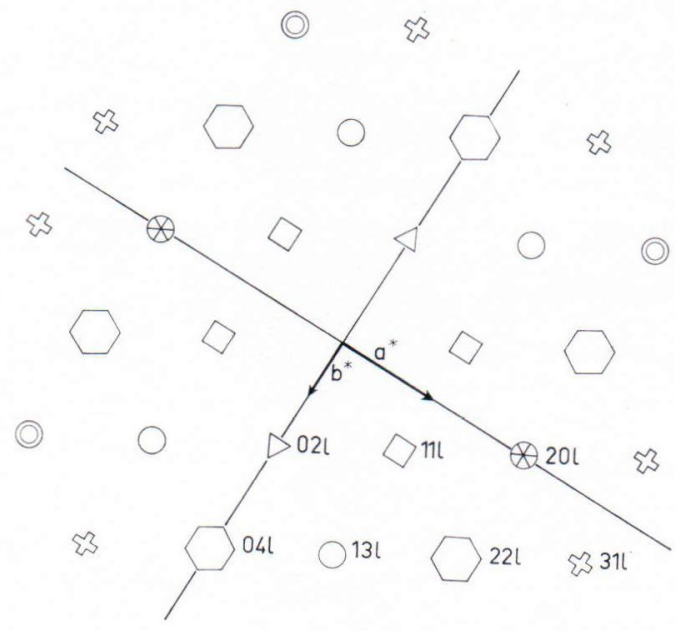

23151

Fig. 12. Schematic representation of the reciprocal lattice projection of the $11 C$-phase along the $c$-axis. The hexagons represent the reciprocal lattice point rows produced by the NiAs-type subcell. The point rows from the superlattice are represented by somewhat smaller symbols. Orthorhombic $a^{*}$ - and $b^{*}$-axes are marked in the figure.

of the features in the precession photographs are still to be solved. In the following, a few observations made on the films are accounted for.

1. When dealing with an orthorhombic space group, systematic extinctions cannot be interpreted in full. The "non space group extinctions», with which it is concerned, may be due to further twinning but also to structural circumstances.

2. In addition to the reciprocal lattice point rows, parallel to the $c$-axis and defining the supercell dimensions in the $a b$-plane, there are some weak reflections belonging to the point rows (also parallel to the $c^{*}$-axis) produced by the NiAs-type subcell, the reflections being consistent with the $11 C$ superstructure. Such reflections are to be seen in Fig. 9 a

3. In reciprocal space, the 112 -point (orthorhombic indexing; see Fig. $10 \mathrm{c}$ ) is the superstructure reflection with the smallest observed $2 \Theta$-value. The distance of this point from the $a^{*} / b^{*}$-plane is, within the accuracy of measurements, $c_{s} / 5.50$, and the distance from 112 - to $1 \overline{12}$ point $c_{s} / 2.75$ (the subscript $s$ refers to the NiAstype sublattice). The difference between these distances and those corresponding to the hexagonal and monoclinic - twinned or untwinned - pyrrhotite superstructures known so far is so large that it excludes the possibility of the $\gg 11 C$ »structure being the result of twinning of any known pyrrhotite superstructure. Also other superlattice reflections allow similar judgements.

4. Fig. 12 shows one pair of reciprocal lattice point rows among the superlattice point rows which are identical but not related by any symmetry operator in orthorhombic crystal classes, namely point rows $31 l$ and $15 l$. These rows can be brought into coincidence by a rotation of 60 degrees about the $c^{*}$-axis. This, however, is the only pair of point rows among the recorded ones which can be brought into coincidence by this procedure. Thus, the pair cannot be due to twinning. 


\section{Dis cussion}

Natural low temperature iron sulphides, based on the NiAs-structure, are represented by the stoichiometric FeS (troilite), the hexagonal slightly iron-deficient pyrrhotite with superstructure and the monoclinic iron-deficient pyrrhotite, which also has a superstructure. Troilite (FeS) and monoclinic pyrrhotite (46.5 atomic percent metals) have constant compositions, whereas the hexagonal iron-deficient pyrrhotites show a small range of solid solution, from 48.1 to 47.5 atomic percent metals (Arnold, 1967).

The data obtained for the Luikonlahti pyrrhotite-troilite intergrowth definitely show the pyrrhotite component to have a symmetry lower than hexagonal and its superstructure to be different from the hexagonal and monoclinic superstructures so far described. In composition the Luikonlahti pyrrhotite corresponds to the hexagonal iron-deficient pyrrhotite described to coexist with troilite as regularly shaped lamellae in some instances (cf.e.g., Kouvo and Vuorelainen, 1962; Kouvo, Vuorelainen and Long, 1963; Carpenter and Desborough, 1964; Clark, 1964, 1966; Arnold 1967). Because many of the descriptions are based on X-ray powder data, the possible occurrence of a phase corresponding to the Luikonlahti pyrrhotite superstructure may have escaped notice.

\section{REFERENCES}

ARnOld, R. G. (1967) Range in composition and structure of 82 natural terrestial pyrrhotites. Canad. Mineral. 9, $1,31-50$.

Arnold, R. G. and Reichen, Laura E. (1962) Measurement of the metal content of naturally occurring, metal-deficient, hexagonal pyrrhotite by an X-ray spacing method. Amer. Mineral. 47, 105-111.

Bertaut, E. F. (1956) Structure de FeS stoechiométrique. Bull. Soc. franç. Minér. Crist. 79, 276-292.

Buerger, M. J. (1947) The cell and symmetry of pyrrhotite. Amer. Mineral. 32, 411-414.

Carpenter, Robert Heron and Desborough, George A. (1964) Range in solid solution and structure of
The crystallization temperature of the euhedral iron sulphide crystals in the fissures of the Luikonlahti serpentinite is an open question. The intergrowth of troilite and iron-deficient pyrrhotite, however, certainly took place at a very low temperature and below the $\alpha$-transformation point at which the $5 C$ superstructure transforms to the $2 C$ superstructure (troilite superstructure). Taking into account the manner of occurrence of the crystals on the walls of open fissures, it is highly probable that the intergrowth took place at temperatures distinctly below $100^{\circ} \mathrm{C}$. It is another question whether the intergrowth is due to selective oxidation of troilite (the zone formation included) or exsolution. It would be most tempting to interpret the intergrowth as having originated through simultaneous crystallization of troilite and iron-deficient pyrrhotite, the formation of the zonal texture having been caused by a small but abrupt change in sulfur pressure during crystallization or by some other change in the $p-T-c$ conditions.

Ackbowledgments - Mr. Jaakko Siivola, Lic.Phil., made the microprobe analyses and Mr. Boris Saltikoff, Mag.Phil., prepared the polished sections of the most minute crystals. Mr. Erkki Halme took the photographs, Dr. Marjatta Okko and Dr. Kai Hytönen read the manuscript critically and made useful suggestions. The author's best thanks to these colleagues.

naturally occurring troilite and pyrrhotite. Amer. Mineral. 49, 1350-1365.

Clark, A. H. (1964) Pyrrhotite-sphalerite relations in the Ylöjärvi deposit, southwest Finland. A summary. Geologi 10, 145-150.

- (1966) The mineralogy and geochemistry of the Ylöjärvi $\mathrm{Cu}-\mathrm{W}$ deposit, southwest Finland: mackinawite pyrrhotite-troilite assemblages. Bull. Comm. géol Finlande 222, 331-342.

Corlett, Mabel (1968) Low-iron polymorphs in the pyrrhotite group. Zeitschr. f. Kristall. 126, 124-134.

Desborough, George $A$. and Carpenter, Robert Heron (1965) Phase relations of pyrrhotites. Econ. Geol. 60, 7, 1431-1450. 
Graham, A. R. (1949) Artificial pyrrhotite. Amer. Mineral. 34, 462-464.

HäGG, G. and Sucksdoff, I. (1933) Die Kristallstruktur von Troilit und Magnetkies. Z. physik. Chem. (B) $22,444-452$.

Kouvo, Olavi and Vuorelainen, Yrjö (1962) Magneettikiisun kokoomuksesta ja rakenteesta. Geologi 14, $79-82$.

- Vuorelainen, Yrjö and Long, J. V. P. (1963) A tetragonal iron sulfide. Amer. Mineral. 48, 511-524.
Mandarino, J. A. and Mirchell, R. S. (1960) Pyrrhotite crystals from the Stanleigh Mine, Elliot Lake, Ontario. Canad. Mineral. 6, 4, 546-548.

Strens, R. G. J. (1964) Magnetite colloid in ore mineralogy. Miner. Mag., 33, 264, 815-817.

Wuensch, Bernhardt J. (1963) On the superstructure and twinning of pyrrhotite. Min. Soc. Amer. Special paper 1, 157-163.

Manuscript received, March 26, 1969. 